\title{
Affirming Non-religion and Humanism through Critical Conversations with Wole Soyinka and Anthony C. Grayling
}

\section{Patrick B.S. Pillay}

\begin{abstract}
The predominance of religion within the academy and South African society has hindered the opportunity for alternate non-theistic worldviews to establish and flourish. Foregrounded in a critique of this centeredness of religion in public life, this paper opens up a conversation between leading academics and renowned humanists and secularists, Professor Anthony Grayling and Professor Wole Soyinka. It is argued that this dialogue will allow the worldview of humanism to re-emerge in new scholarship, within a non-religious framing and with a secular outlook. The biographies of the discussants are considered as indicators of how context shapes personal epistemologies and non-religious identities, in this instance revealing how backgrounds as dissimilar as Soyinka's and Graylings find the worldview of humanism as a point of convergence. The Soyinka-Grayling dialogue challenges theocentric orientations to education and highlights the urgency for limitations on the influence of religion in education, to make way for the re-envisioning of the Humanities.
\end{abstract}

Keywords: Humanism, Wole Soyinka, Anthony C. Grayling, non-religion, religion, secularity

\section{Introduction}

The case for new scholarship in South Africa in the fields of non-religion, secularity and humanism is more than about a critique of religion. The project to establish new public and academic space for this set of allied and complementary constructs is aimed at understanding alternate perspectives to shaping the public sphere and public policy, perspectives which may not have 


\section{Patrick B.S. Pillay}

enjoyed anywhere near equal time in public and academic discourses due to the history and weight of religious normativity in the country. The premise and motivation for this paper is the need to affirm the worldview of non-religion and humanism to not just answer the questions which religion no longer sufficiently can but to point to a more embracing, meaningful and genuinely pluralistic social order.

Something needs to be said, however, about the increasing importance for public and academic debate on how the centeredness of religion in relation to public life may be shifting. Whilst the South African constitutional dispensation of 1996 is certainly a departure from the past's privileging of religion, and a particular brand of religion at that, the public space remains highly contested when related to matters of religion. Being tied to the global community South Africa cannot be closed to the shifts in religiosity and the forms in which religion as a social marker is evolving. That religion can be an instrument of power and empire is undeniable and a post-1996 constitutional order requires an equitable disposition which safeguards against the risks associated with the hegemony of religion. The need, however, to establish the field of non-religion, secularity and humanism is growing in significance, driven simply by social, political and demographic shifts which derive from a more open and inclusive constitutional framework (Lee 2015; Zuckerman 2014). In what has become a battleground of ideas on these issues two acclaimed academics have been at the forefront of the cause for a non-theistic worldview not beholden to any supernatural deity, the authority of Scriptural texts, or any religious order.

This paper aims to bring into conversation the life and works of Nigerian playwright Wole Soyinka with that of British born philosopher, Anthony C. Grayling. Their markedly different biographies and philosophical grounding do nothing to diminish what could be regarded as their common voice in the cause for a non-theistic humanism. The intellectual rigour, philosophical depth and the social and political activism evident in the work and lives of both Anthony Grayling and Wole Soyinka serves as a unique resource for new scholarship in the field of non-religion and humanism. Having said that, it is noted that this paper is not a literary assessment of the works of Grayling or Soyinka, rather one which brings together their work in shaping this new field within the Humanities. More than their proximity to the subjects under consideration, their commitment to making philosophy accessible to non-specialist audiences has over the years opened up instances 
for public engagement which might not otherwise have been had.

In many respects both Anthony Grayling and Wole Soyinka have been revolutionary in cutting across the consensus and predominance of religion to illuminate the idea of liberty of conscience, the power of intellectual autonomy, the cause of human rights and the real possibility of harmonising individual rights with the well-being of society. In understanding their contributions in these areas this paper also aims to explore the possible intersections between the philosophical traditions which inspired Soyinka's and Grayling's life's work. The question is raised as to whether there can be a newfound synthesis between Wole Soyinka's humanism inspired by African spirituality and Anthony Grayling's Western, Enlightenment inspired humanism.

\section{Personal Biographies and the Development of Non-religious Identities}

It has been through new media resources that many were introduced or reintroduced to the biographies and works of these thinkers, with the opportunity to read, see and hear current accounts of their work, as well as their reflections on works past. For a project of this nature, these electronic resources/libraries have been invaluable in constructing the case for a new academic discipline in South Africa, and one which serves to link South Africa and Africa with the growing international network in the field of non-religion, secularity and humanism.

Both Wole Soyinka (Born Akinwande Oluwole Babatunde Soyinka, 13 July 1934) and Anthony Clifford Grayling (Born 3 April 1949) were born in Africa and both had early childhoods within the Anglican Church. Wole Soyinka's father was a priest in the Anglican Church and although 'high church' was their way of life, Soyinka was still drawn to his Yoruba heritage.

His parents are of course uncompromising in the cause of Christianity, High Church Anglican variety, but the growing Soyinka is powerfully drawn in as yet inexplicable ways to the world of Yoruba rituals and festivals (Jeyifo 2004:197).

Wole Soyinka was born in the village of Ake' in Yorubaland (South West Nigeria) in the town Abeokuta. His primary schooling was completed at St. 


\section{Patrick B.S. Pillay}

Peters Anglican Primary School where his father was head teacher. Despite what might have developed in his social activism in later years and his responses to religion it is evident his formative years and particularly his schooling experience were deeply influenced by the church. Wole Soyinka attended the Abeokuta Grammar School the property of which also became the seat of the Anglican Bishop of Nigeria. It was here at his secondary school that his writing abilities were seeded. According to Bishop Dapo Asajo, 'The academic erudition of Wole Soyinka, the cultivation of his academic virtues, his strength, was built here [Abeokuta Grammar School]' ${ }^{1}$. It is significant that Bishop Asajo also describes the close relations enjoyed between the Soyinka and Ransome-Kuti households. The Ransome-Kuti family were known to be very strong social activists and well educated. Referring to Nigeria's renowned music artist Fela Kuti as Wole Soyinka's cousin Bishop Asajo notes that both shared rooms at Abeokuta Grammar School (6.40 minutes).

If 'context matters' then Wole Soyinka's context mattered completely. There was the proximity of the church as well as his strong links with his indigenous religious and cultural heritage, that of the Yoruba people. These religious contestations were set against the backdrop of a history and political reality, at least for the better part of his early childhood ${ }^{2}$, of colonial rule. Soyinka admits to being made conscience of this within his household and from discussions which his parents and extended family held about Nigeria under British colonial rule. The seeds for Soyinka's life as a writer and activist are attributed to his parents.

I grew up in a community, family environment in which the sense of nationalism was quite strong. My uncles, my parents used to argue quite a lot ... this discussion was going on and so there were manifold aspects of viewing our condition and I was bombarded .... I was a curious child, I was very curious child, I was bombarded with many aspects, different aspects of that ${ }^{3}$.

${ }^{1}$ CGTV News. 2016. Faces of Africa - Wole Soyinka: Glutton of Tranquility. Available at: https://www.youtube.com/watch?v=FhrOwxoOomk\&t=10s (Accessed on 3 November 2019.)

${ }^{2}$ Wole Soyinka describes his early childhood in his autobiographical work, Ake': The Years of Childhood, published in 1981.

${ }^{3}$ CGTV News. Faces of Africa - Wole Soyinka (05.16 minutes). 
It was this context which set the tone for much of Wole Soyinka's work and social activism, which continued after colonial rule had ended. These varied aspects which were formative in shaping his identity became manifest in his work and throughout his life, that is, an ongoing critical reflection of his social reality and the need he felt to be a part of his own liberation and that of his country and the continent. Brenda Cooper (1995:49) in her article, The TwoFaced Ogun: Postcolonial Intellectuals and the Positioning of Wole Soyinka, notes that Soyinka and other African writers like him,

assert an African nationalism that depends on excavating a precolonial African past which, in different ways, they exhume as the basis for purging their societies of the evils of cultural imperialism. In this way they propose to 'decolonise' their cultures. Again I need to emphasise that while African writers like Achebe, Aidoo, Armah and Ngugi are radically dissimilar, they share (albeit different versions of) this underlying nationalism.

The tension between Soyinka's African traditional past and what could be considered as the western influences upon his life, as represented by the Anglican Church and the fact that his mother was a devout Christian and his father a vicar and teacher in the Anglican Church, became to define his life and his work. Moffat Moyo (2014:197) notes that it was his grandfather who introduced Soyinka to the assemblage of the characters and gods of the Yoruba people which found their way into Soyinka's writing and philosophical outlook. In more than just his writing, it was in his social activism and responses to the political repression which he went on to experience first-hand that these tensions played out, thereby allowing a lifelong repository of indigenous knowledge from which to draw.

He envisioned a 'New Africa' that would escape its colonial past by grafting the technical advances of the present onto the stock of its own ancient traditions. Native myth, reformulated to accommodate contemporary reality, was to be the foundation of the future, opening the way to 'self-retrieval, cultural recollection, [and] cultural security .... Soyinka dreamed instead of a truly de-colonized continent, where an autonomous African culture assimilated only those progressive elements of recent history that were consistent with its 


\section{own authentic identity ${ }^{4}$}

It would be one thing to assert that this tension which derived from Soyinka's reaching into his rich African heritage on the one hand and the reality of his Christian family, schooling and social contexts on the other, was indelible in crafting his literature with which the world is gifted. It is another, however, to attempt to discover how these tensions influenced Soyinka's disposition towards religion, non-religion, the place of religion in matters of State and public policy formation and the construction of a worldview of humanism. Unravelling these issues and particularly Soyinka's attitude towards religion cannot be set aside from his entire approach towards injustice, corruption and the suppression of the will of the people.

As was said of Fela Anikulapo-Kuti by Justin Labinjoh (1982:119) the same could be attributed to Wole Soyinka.

Biographical experiences result from a combination of several phenomenon, one of the most important of which is the individual's consciousness, which not only structures his perception and interpretation of the social world, but also activates his specific social action.

In the same social and country contexts of his cousin Fela Kuti and in the midst of what could be regarded as a post-colonial conundrum, in that the state of affairs in Nigeria and post-colonial Africa did not turn out as they had wished, Wole Soyinka's works of resistance and protest took shape. The post-colonial battle lines were being drawn for Soyinka by corrupt and despotic governments which would test and shape his resolve.

Following completion of high school in Lagos, Soyinka attends University College, Ibadan (1952-1954) before a five year stay (1954-1959) in the United Kingdom, where he completes a BA Honours Degree (English) in 1957. By the time of his return to Nigeria in 1959 Ghana had already achieved independence (1957) from colonial rule, setting in place the wave of postcolonial changes which was to follow throughout Africa.

${ }^{4}$ Stanford University. Presidential Lectures in the Humanities and Arts: Wole Soyinka. Available at: https://prelectur.stanford.edu/lecturers/soyinka/. (Accessed on 15 September 2019.) 
During the tumultuous decade in Nigeria, post-independence in 1960, Wole Soyinka was actively involved in the resistance movements and workers movement strikes. Jeyifo (2003:xxv-xxvi) notes of Soyinka's preparedness to forego his appointment as a lecturer (1962) at the University of Ife because the university had chosen to align with the government which was considered unpopular. The 1965 incident of the mystery gunman who held up a Nigerian Broadcasting Service radio station at Ibadan to broadcast his version of the election victory claimed by President Samuel Akintola, remains a mystery. Wole Soyinka was acquitted in court for involvement in the incident ${ }^{5}$.

In 1967 Soyinka was arrested and imprisoned for 22 months, most of which was spent in solitary confinement ${ }^{6}$. This brief set of extreme life shaping events reflects within Wole Soyinka's life and works and how he chose to engage his social reality ${ }^{7}$. As complicated as it may appear, Soyinka lays bear his core philosophical motivations during an interview (16 ${ }^{\text {th }}$ April 1998) with Harry Kreisler, titled Conversation with History: Writing, Theatre Arts and Political Activism.

${ }^{5}$ Commentators and biographers appear to remain in disagreements about Soyinka's hand in the incident. Lawrence Ugwuanyi (2011:77) cites, albeit recklessly, the incident as an example of Soyinka's 'subverting ideals and going against conventional norms and values'. James Gibbs (1993:240) notes, 'He decided to hold up the radio-station at Ibadan and broadcast a tape he had made which began 'this is the voice of Free Nigeria' and went on 'to advise Chief Akintola and his crew of renegades to quit the country'. After he put the tape on, Soyinka left the radio-station and, in his own words, 'went into hibernation'. He was eventually brought to trial and acquitted - on the grounds that 'there was conflicting evidence'.

${ }^{6}$ University of California Television. 2002. Conversations with History: Wole Soyinka. Available at:

https://www.youtube.com/watch?v=wosbdri9dRc\&t=372s.

(Accessed on 7 October 2019.)

${ }^{7}$ Wole Soyinka's biographical accounts could be found in five of his works, The Man Died: Prison Notes of Wole Soyinka (1972); Ake: The Years of Childhood (1981); Isara: A Voyage Around 'Essay' (1989); Ibadan: The Penkelmes Years: A Memoir, 1946-1965 (1994); and You Must Set Forth at Dawn (2006). 
Harry Kriesler (26.02min): We've talked about truth and society and the transformative possibilities of theatre, what about the relationship of truth to power?

Wole Soyinka (26.18min): Well, the first thing is that the truth and power, for me, form an antithesis, an antagonism which will hardly ever be resolved. The ... I can define in fact, I can simplify the history of human society, the evolution of human society as a contest between power and freedom. Now that we mention the word power and whether this contest is being performed along ideological lines or along religious lines, ultimately really, what we have is truth versus power. Truth for me is freedom, is self-destination. Power is domination, control, and therefore, a very selective form of truth, which is a lie. The polarity ... the polarity between these two in fact forms for me the axis of human striving in the creation of an ethical society, ethical community.

These insights inspired the project to discover the congruencies between the life and work of Wole Soyinka and Anthony Grayling. The principles which stand out from Soyinka's statement are, firstly, to grasp the truth for one's life, whatever that may actually turn out to be, one must have the freedom to engage that pursuit. Secondly, that pursuit, without outside domination and control is central to the makings of an ethical society. These are philosophical threads which weave through the work of both Soyinka and Grayling. Implicit in these positions, however, is a contestation to religion itself and its place in the organisation of society. This paper seeks to negotiate beyond just an oppositional stance to religion to establish and positively affirm a worldview without the dictates of religion. The direct implication of this stand is that the ethical and moral life and the ordering of an ethical society could be had without a mandatory place for religion, Holy Scriptures and divine revelation. The rediscovery, reframing and re-articulation of this non-theistic worldview, it is argued, are the life's work of both Wole Soyinka and Anthony Grayling.

Anthony Grayling was born in Zambia and raised in Malawi where his father worked as a bank official within Standard Chartered Bank. He was the youngest of three children, having an elder brother and sister. In an interview in 2015 with journalist Fionnuala McHugh, Anthony Grayling notes that his 
parents were completely non-religious. For what might have appeared to Wole Soyinka in his early childhood as a communal discovery of matters philosophy for Anthony Grayling it was a solitary experience. At the age of 12, philosophy struck when Grayling discovered the works of Plato in a public library. After coming upon the work of English philosopher G.H. Lewes at the age of 14 he had decided that the study of philosophy would be his career ${ }^{8}$. As a teenager Grayling returned to England, completed his schooling and commenced his undergraduate studies.

Anthony Grayling's link with South Africa came by way of personal tragedy when he was 19 years old. His sister Jennifer was murdered in Johannesburg. He visited South Africa with his parents to attend to the matter, which had a lasting impact on him. Grayling notes that the incident worsened his mother's heart condition and she passed on a few weeks after his sister's death ${ }^{9}$.

For both Anthony Grayling and Wole Soyinka, childhood and early adult life reflected a convergence which was complex, deeply contemplative and brutal, through personal tragedy and loss in the case of Grayling and through imprisonment, State harassment and forced exile in Soyinka's case. It cannot be lost on any project of this nature that Soyinka and Grayling grew up on either sides of the spectrum of colonisation. Grayling was born and raised in what was an expatriate enclave with what he refers to as the life of 'Edwardian-style magnificence, made easy by servants in crisp, white uniforms' (Wintel 2013). Soyinka on the other hand took on the mantle of resistance to colonialism into which he was born.

Given his profile within the academy and society it was inevitable that Anthony Grayling would be drawn into what became known as the New

${ }^{8}$ McHugh, F. 2015. A.C. Grayling on how religion imprisons societies and why he can't get a China visa. Post Magazine. Available at: https://www.scmp.com/magazines/post-magazine/article/1883168/acgrayling-how-religion-imprisons-societies-and-why-he-cant.

(Accessed on 20 September 2019.)

${ }^{9}$ Wintle, A. 2013. A C Grayling on Growing Up, Discovering Philosophy and the Meaning of Life. The Telegraph. Available at:

https://www.telegraph.co.uk/culture/culturenews/9933425/A-C-Grayling-ongrowing-up-discovering-philosophy-and-the-meaning-of-life.html. (Accessed on 20 September 2019.) 
Atheist movement globally, alongside Richard Dawkins, Sam Harris, Daniel Dennett and Christopher Hitchens. It was, however, Anthony Grayling's roots within formal academic inquiry on philosophy which shaped, firstly, his resistance to faith-based religion and secondly, his commitment to the worldview of the secular, the non-religious and to humanism.

\section{Identities, Knowledge and Non-religion}

The question has to be posed of Soyinka and Grayling and an answer attempted, as to how their respective non-religious identities became to be what it is. It is only in recent years that the study of non-religion has emerged as a challenge to the notion that it is a mere absence of religion (Strhan \& Shillitoe 2019; Lee 2015; Beaman \& Tomlins 2015). Central to these studies, as a key contribution to this new field of research, is the question as to how nonreligious identities are constructed.

In the case of Grayling and Soyinka, the arts, classical antiquity and literature generally, were the driving elements to what appears to be selfconstructed non-religious identities. The Credo of Being and Nothingness was, according to Biodun Jeyifo (2003:74) 'Soyinka's most important reflection on religion and human spirituality in the closing decades of the twentieth century'. In Soyinka's case his strong critique and the satirising of religion was already present in his 1964 play The Trials of Brother Jero. In this work Soyinka demonstrates that he was already strongly opposed to monotheistic religion and cognisant of the harm it was having on society. According to Patricia Mireku-Gyimah (2013:282),

It [The Trials of Brother Jero] has considered Soyinka's use of irony, exaggeration and invective as tools of satire to hammer home his bitter criticism of religious and political roguery that have become rampant worldwide particularly in post-colonial Africa and his own Nigerian society. We have noted that hardened criminals in the form of ruthless, quack prophets and power-drunken politicians must persistently be exposed to prick their consciences to effect the necessary changes in order for all to enjoy personal freedom and peace. And Soyinka shows the way by ridiculing the perpetrators, his general preoccupation being largely corrective. He also discourages ordinary Africans from permitting themselves to be duped. 
Wole Soyinka's critique of religion, therefore, was deeply rooted in his concern for community and country, to curtail the influence, racketeering and the monetising of religion that he had witnessed. For him religion represents the power to dominate and control and not the 'truth' and the freedom and selfdestination which he revealed in the Harry Kreisler interview. However, he also saw in the monotheistic religions the construction of their own inconsistencies. By their very nature they were exclusivist, alienating and hence prone to radicalisation. In his analysis of Soyinka's The Credo of Being and Nothingness, Biodun Jeyifo (2003:76) makes the following assessment.

In this respect, the essay implicitly but forcefully critiques the unacknowledged theological or doctrinal predisposition toward exclusivism in all the dominant monotheistic religions of the world, a predisposition which, in Soyinka's opinion, haunts these religions' efforts at ecumenism and mutual tolerance.

From the foregoing, it can be readily perceived that 'The Credo of Being and Nothingness' deserves attention as a vigorous restatement of many of the radical-humanist, intercultural and internationalist themes of Soyinka's essays of the 1980s.

Lawrence Ugwuanyi (2011:68-69) locates Soyinka's life and work within the philosophy of existentialism, with him being concerned with the human drama and how 'themes as freedom, justice, courage, power define and authenticate the human quest for meaning and value'. It was, however, the African spirituality of his childhood, instilled by his grandfather and family which represented the 'truth' for Soyinka. This worldview embraced a multiplicity of 'Gods' and religions whilst allowing Soyinka the freedom to his self-destiny, even if that may be non-theistic. The characterisation of Soyinka as a 'radical theistic humanist' by Celucien Joseph (2015:19) has more to do with the central place of African indigenous spirituality in the life of Soyinka and less, much less, to do with the monotheistic Abrahamic religions. It is from this African indigenous resource (Yoruba tradition) that Soyinka draws his construction of universality and pluralism in which nobody is an outcast (23.34 minutes) and that Yoruba culture is embracing of differing systems of belief or religions. Soyinka (12.45 minutes) notes that, 'If you are seeking ultimate truth you must be prepared to travel by different routes' .... (13.30 minutes). 'The 
rigidity which is practiced let us say by other religions, you know, doesn't exist at all in Yoruba culture, ${ }^{10}$.

Anthony Grayling has been immersed in the study of philosophy from the time he picked up the works of Plato in a Zimbabwean library. This has also meant a lifetime's work of making the field of philosophy more accessible to the general public, through written works and in recent years through the publication of lectures and discussions on new media channels. Grayling completed his Doctorate in Philosophy in 1981 (Title, Epistemological Scepticism and Transcendental Arguments which was published in 1985 as a monograph The Refutation of Scepticism). If Grayling's early work could fit an academic category it would be the Theory of Knowledge, central to which for Grayling was the study of scepticism, as summarised in the following extract from Scepticism and the Possibility of Knowledge (2008:xi).

The study of scepticism might be said to define epistemology. As the enquiry into the nature and sources of knowledge, epistemology's twofold concern is to identify and examine the conditions whose satisfaction will amount to knowledge. Familiarly, one of these crucial conditions is justification. The problems facing the justification of knowledge-claims can best and most powerfully be described by framing them as sceptical challenges, meeting whichif possible - will certify that we are at least sometimes entitled to make claims to knowledge.

This extract does start to answer the question posed earlier as to the makings of non-religious identities. In its essence the formulation of knowledge as proposed by Grayling stands diametrically opposed to the accepting/making of any claim based on religious faith. It could be argued that at the core of Grayling's work was his framing of what the basis of knowledge was. Grayling argues that there is nothing noble about believing in something based on unsupported evidence and ancient superstition and notes that, 'Faith is a commitment to belief contrary to evidence and reason' (2007:8).

${ }^{10}$ Haus Der Kulturen Der Welt. 2016. Dictionary of Now \#3 | Wole Soyinka \& Manthia Diawara - TRUTH. Available at:

https://www.youtube.com/watch?v=GQxFBe_JgrA

(Accessed on 15 November 2019.) 


\section{Re-envisioning the Humanities: A Non-religious Frame}

This commitment for Anthony Grayling and indeed for Wole Soyinka took on very real meaning in their lives through their commitment to the advancement of the Humanities within systems of education which they felt was foundational for the development of societies themselves. The need, therefore, to strengthen the faculties of literature, history and philosophy within the academy along the lines of a secular, humanist worldview remained important.

It was at a lecture at the University of Johannesburg (SA) in 2016 that the full might of Wole Soyinka on the influence of religion on education was felt $^{11}$. The event was The BRICS and Emerging Economies Universities Summit held in collaboration with Times Higher Education, with the theme of the summit, 'Reimagining the world-class university' ${ }^{12}$. Soyinka was scathing in his critique of religion as a force which seriously impedes the creation of knowledge and negates the very idea of what a university should be. His account of the Nigerian experience was personal and heartfelt; bearing witness to the wide scale disruption of education at schooling and university level by religious forces (2.25 minutes). The lecture also brings to mind the significant difference between Grayling and Soyinka's paths to humanism as a worldview. The difference is the sheer violence which marks the Nigerian experience, at the hands of what Soyinka describes as religious fundamentalist groupings, such as Boko Haram, and Daesh/Islamic State in Iraq and Syria. Despite this difference both Grayling and Soyinka shared an urgency for a solution, at least within the realm of education.

Knowledge, let us all admit the obvious, is an inexhaustible affair. It holds many of us enthralled and will probably continue to do so long

${ }^{11}$ University of Johannesburg. 2016. BRICS16 Day 1: Wole Soyinka Keynote Address. Available at: https://www.youtube.com/watch?v=r5j3-5c82ME\&t=115s.

(Accessed on $5^{\mathrm{h}}$ December 2019.)

12 Times Higher Education. 2016. THE BRICS \& Emerging Economies Universities Summit to Take Place in Johannesburg. Dated $7^{\mathrm{h}}$ October 2016. Available at:

https://www.timeshighereducation.com/world-university-rankings/bricsemerging-economies-universities-summit-take-place-johannesburg. (Accessed on 3 November 2019.) 
after we are able to consummate its intellectual lust. And so it is time that we began to think of reverting to that principle of intellectual inquiry for its own sake. Only this time privileging the materialist tendency against the outward directed. Objectively and in a spirit of inquiry the secular bias deserves its own time and orientation, and in a mode of concentration that compensates for centuries of theocratic privilege, however thinly disguised. To put it harshly, the theocratic has exacted such a heavy toll on the intellectual pursuit both in ancient and recent times that drastic strategies are mandated for weening the young mind away from the revelationary overlay on material manifestations even of the unacknowledged subliminal level. Wole Soyinka (24.09 minutes).

The case made by Soyinka for humanism at the lecture was an uncompromising pushback to the influence of faith-based religion in education. From the outset of his lecture, 'A University of the Future: A Humanist Reimagines', Soyinka declared the constructs of secularity and humanism as comprising the philosophical and intellectual model upon which to build the university of the future. ${ }^{13}$

At an event in Ghana in 2015 in support of education, arts and culture, Wole Soyinka was hosted by Access Bank Ghana in line with the Bank's 'drive to inspire and nurture the youth to cultivate critical thinking and creativity in literature and the arts in general'. His appeal was that of a humanist, plain and powerful.

Education remains a critical aspect in the development of any nation as it unlocks the thinking canals of our youth. However, a holistic education that encompasses the ability to help children appreciate their humanity and show empathy to their fellow human beings is

13 Times Higher Education 2016. Wole Soyinka: ‘Anti-humanism' Infecting Universities. Dated 1 December 2016. Available at:

https://www.timeshighereducation.com/news/wole-soyinka-anti-humanisminfecting-

universities\#: :targetText=That $\% 20$ is $\% 20$ the $\% 20$ powerful $\% 20$ message, youn g\%20mind\%20away\%E2\%80\%9D\%20from\%20dogma.

(Accessed on 12 November 2016.) 
what guarantees a prosperous nation ${ }^{14}$.

In describing the risks to the Humanities, to the 'cultivation of ideas' and 'knowledge production' in Nigeria and in Africa, Olufemi Taiwo (2009:262) highlights that,

What we have instead is a proliferation of religious fervor and both Muslim and Christian sects. In other words, in a perverse example of a self-fulfilling prophecy, Lugard's insistence that Africans did not need an education of the intellect but moral and practical education with a generous dose of religion has become the dominant model in Nigeria'15.

\section{The Worldview of Humanism and a Human Rights Paradigm}

In trying to understand the makings of a system of education based on humanism John White (2015:234) distils from the works of humanist thinkers/writers Bertrand Russell, Harold J. Blackham and Jeaneane Fowler the central idea of education being directed at developing an individual's intellectual autonomy. John White quotes Jeaneane Fowler's humanist conception of education as being associated with, 'autonomy, critical thinking, the development of the whole person, the rejection of a narrow vocationalism'. It could be fairly deduced from Soyinka's body of work that there was and indeed continues to be an intense struggle between the forces in favour of this humanist worldview and that which proclaims Scriptural texts and divine revelation as the basis for the 'absolute truth'. At the World Humanist Congress 2014 at which he was

${ }^{14}$ Ghana Business News. 2015. Access Bank Hosts Professor Wole Soyinka in Ghana. Available at:

https://www.ghanabusinessnews.com/2015/07/03/access-bank-hostsprofessor-wole-soyinka-in-ghana/. (Accessed on 12 November 2019.)

${ }^{15}$ In the chapter (4), Reading the Colonizer's Mind: Lord Lugard and the Philosophical Foundations of British Colonialism, Taiwo set out the colonial context of Nigeria and the continent and how the choices made by the colonial leaders such as Lord Frederick Lugard with regard to the direction of education actually impacted the development of societies in subsequent decades. 
awarded the International Humanist Award, Wole Soyinka noted the following of charismatic preachers, religions and gods.

They are areas of interest, often of mystification, but should never be allowed to obscure the fundamental truth as it affects the rest of us: that the conflict between Humanists and Religionists has always been one between the torch of enlightenment and the chains of enslavement. And let me state that one wishes that we were speaking merely of invisible chains ${ }^{16}$.

In her presentation of the award to Soyinka, Patricia Rogers, a trustee of the British Humanist Association noted,

In the sharpest possible contrast to the terrorist Boko Haram's dichotomous disavowal of 'western education' as alien to their world, Soyinka has long been the intellectual leader of distinctively African voices within the universal Enlightenment tradition ${ }^{17}$.

It is through this very Enlightenment tradition of the $16^{\text {th }}-18^{\text {th }}$ centuries that Anthony Grayling developed his body of scholarship. Irrespective of how one may wish to understand or accept the outcomes of the period of the Enlightenment it is undeniable that the Enlightenment values which emerged from this period changed the course of human history. Humanism as it has developed into the modern era emerged from this period, in particular the $18^{\text {th }}$ century. Tzvetan Todorov (2002:6-7) in his work Imperfect Garden: The Legacy of Humanism made the point that 'Humanism is the ideology underpinning modern democratic states; but this very omnipresence makes it invisible or insipid'. It will be fair to say, though, that Anthony Grayling has

${ }^{16}$ Humanist International 2014. Wole Soyinka's International Humanist Award Acceptance Speech. Dated 12 August 2014. Available at:

https://humanists.international/2014/08/wole-soyinkas-international-

humanist-award-acceptance-speech-full-text/.

(Accessed on $12^{\text {th }}$ November 2019.)

This speech was presented in absentia due to Soyinka's ill health at the time.

${ }^{17}$ Humanist International 2014. Wole Soyinka's International Humanist Award Acceptance Speech. 
been a leading scholar in universalising the Enlightenment tradition and the worldview of humanism with the similar vigour as Wole Soyinka and for reasons not dissimilar to Soyinka's; that humanism should inspire our quest for a meaningful life, in the here and now, in this one life which we will pass through ${ }^{18}$. Grayling's book The Age of Genius: The Seventeenth Century and the Birth of the Modern Mind offers a focused appraisal of the Enlightenment of that period. At a public lecture to mark the $150^{\text {th }}$ anniversary of the publication of Charles Darwin's book On the Origin of Species, Anthony Grayling summarised his views on these points.

So you have rationality, the rational proportioning of evidence to the claims that you make or the places you're going to rest your confidence on for the time being until other evidence comes along and it's the contextualisation of that inquiry that helps you to make sense of this world. When you apply those two things, rationality and contextualisation to any of the claims of any of the religions of antiquity you come to an understanding of why it is that there are so

18 Tzvetan Todorov's (2010:170) explanation of these connectivities is quoted in its entirety (regrettably with its non-neutral gender references) as it captures the idea of Humanism as it has developed through the works of both Anthony Grayling and Wole Soyinka. 'The age of the Enlightenment, which synthesized and systematized the thought of the previous centuries, would here occupy a major place. One of its contributions would be the idea of autonomy, which means that every human is able to know the world by himself and to influence his own destiny. Just as the people are sovereign within a democracy, the individual can become so, to a degree, within his personal sphere; as a result, the very idea of democracy is transformed, since it simultaneously guarantees the power of the people and the freedom of the individual, including his freedom from that power. The eighteenth century also witnessed the advent of humanism, in other words the choice that consists in making man into the final aim of human action. The aim of human existence on earth is no longer to seek the salvation of his soul in the beyond, but to attain happiness here below. The acknowledgement of a legitimate plurality, whether it be that of religions, cultures or indeed powers within a state, is also part of the legacy which the Enlightenment has bequeathed the history of humanity: pluralism becomes a value within itself'. 
few religions left.....Well, this is something, an example of how use of scientific styles of thought, not science itself, particularly, but scientific styles of thought, as happened in the Enlightenment, and we are still I think in the, as it were, the phenotype of the $18^{\text {th }}$ Century Enlightenment, we are it. But, these ways of thinking about things help us in our thinking about the problems of society and how to construct the individual good lives in society and it helps us also to explain why increasing numbers of us are no longer content to accept and even indeed to respect the existence of worldviews which are neither rational nor contextualised ${ }^{19}$ Anthony Grayling (2009) (28.12 minutes).

Whilst Wole Soyinka was clearly aligned with the Enlightenment tradition and the worldview of humanism that it inspired, he was not confined to the Western/Euro-centric location of this worldview. In what could be interpreted as a richer contribution to the philosophical architecture of humanism, Soyinka's African and Yoruba 'contextualisation' brought tangible clarity to the inherent potential paradox within humanism of individual autonomy in relation to the interests of community/society. Tzvetan Todorov (2002:139) also expressed this fundamental challenge of having to balance individual liberties whilst at the same time embracing society's common values and interests but expressed that 'French humanists, from Montaigne to Tocqueville, believed in the possibility of the freedom of modern man in relation to his particular community', Celucien L. Joseph (2015:42) summarised Soyinka's position as follows.

It is indisputable that Wole Soyinka is a champion of humanist values and religious inclusivism. Soyinka has modelled an exemplary life of public intellectualism and literary ingenuity, through which he promotes humanism as a worldview, and African spirituality as an alternative to the Abrahamic religions. In regard to this matter, we suggest that the theoretical notions of radical theistic humanism and

${ }^{19}$ Humanist UK. 2009. Anthony Grayling: Darwin, Humanism and Science, Conway Hall. Dated 6 June 2009. Available at:

https://www.youtube.com/watch?v=HbeY9_NErCs.

(Accessed on 5 November 2019.) 
generous tolerance best summarize Soyinka's ideals and systems of thought.

More than their contributions to the school of thought of humanism and its non-theistic framing, Wole Soyinka and Anthony Grayling have both applied their convictions and philosophy in the public sphere. Grayling and Soyinka will forever occupy respected space in areas concerning human rights and the advancement of individual liberty in solidarity with the well-being of society. At the Canadian Museum for Human Rights, on 16 September 2013, Anthony Grayling expressed what could be regarded as the central idea which seeded his work in the area of human rights, that being 'liberty of conscience ${ }^{20}$ (5.22 minutes). An accompanying right to this is that of the freedom of expression which is also pivotal to the humanist outlook. At the 2014 World Humanist Congress, with the theme of 'Freedom of Speech and Freedom as such', Anthony Grayling made the following comment ${ }^{21}$ (21.41 minutes).

Now go back to what I said right at the outset about the central importance of freedom of expression to the very possibility of possessing rights and of having a healthier and flourishing social order, that when people can't express their views and challenge other people's views, when people can't explore alternatives and different ways in which we might live our lives as individuals and construct our societies, the result is going to be stultification. It's going to be a loss of a huge amount of human potential and possibility .... (22.55 minutes). So it seems to me that it's not just a matter of defending our outlook and having an instrument available to us, the instrument of speech, of challenge, of exploration and enquiry by means of which we can challenge the believers in witchcraft in Africa, we can

${ }^{20}$ Canadian Museum for Human Rights 2013. A.C. Grayling| Human Rights: Past and Future. Dated 16 September 2013. Available at:

https://www.youtube.com/watch?v=eahIiCgYS88.

(Accessed on 5 November 2019.)

21 Humanist UK 2014. World Humanist Congress: Plenary One - A.C. Grayling on Freedom of speech and freedom as such. Available at: https://www.youtube.com/watch?v=16aWcPm4w_4. (Accessed on 6 November 2019.) 
challenge the adoption of faith based schooling in advanced economies, that we can argue against the repressions and disabilities imposed on women by many of the major religions. It's not just a question of defence and attack, it's a question of whole societies being able to take advantage of this wonderful thing that human beings have, even though you may sometimes think they don't have it, and that is intelligence. Freedom of expression is the root by which human intelligence can seek the best and do the best in our world.

\section{Conclusion}

Humanism is premised on humans being an intelligent species with their own will and ability to order society to ensure the autonomy of the individual as well as the well-being of society. This social ordering is established through a set of laws and rights which safeguards individual liberties and through the universal application of such rights to every citizen. This paper explores the emerging research field of non-religion, secularity and humanism as a contribution to new scholarship within the Humanities. The conversation opened up in this paper between world renowned humanists Professor Wole Soyinka and Professor Anthony Grayling affirmed the non-theistic worldview of humanism as a response to and a critique of the influence of religion in public affairs and in particular, its influence within the academy and systems of education. The Soyinka-Grayling dialogue served to link African interpretations and understandings of non-theistic humanism to the international community of scholarship in this field; holding out the promise that African scholarship will have new contributions to offer to the field of non-religion and humanism.

\section{References}

American Humanist Association. Humanism and its Aspirations - Humanist Manifesto III (2003). Available at: http://americanhumanist.org/wpcontent/uploads/2018/08/HumanismandItsAspirations jefferson1.pdf.

(Accessed on 28 November 2019.) https://doi.org/10.16995/ntn.863

Beaman, L.G. \& S. Tomlins (eds.) 2015. Atheist Identities - Spaces and Social Contexts. New York: Springer. 
Bhargava, R. 2004. Inclusion and Exclusion in South Asia: The Role of Religion. United Nations Development Programme: Human Development Report Office - Occasional Paper, 2004/1, pp.1 - 48.

Canadian Museum for Human Rights. 2013. A.C. Grayling| Human Rights: Past and Future. Dated 16 September 2013. Available at:

https://www.youtube.com/watch?v=eahliCgYS88.

(Accessed on 5 November 2019.)

CGTV News. Faces of Africa - Wole Soyinka: Glutton of Tranquility. Dated $2^{\text {nd }}$ February 2016. Available at:

https://www.youtube.com/watch?v=FhrOwxoOomk\&t=10s.

(Accessed on 3 November 2019.)

Cliteur, P. 2010. The Secular Outlook: In Defense of Moral and Political Secularism. West Sussex: John Wiley and Sons Ltd.

https://doi.org/10.1002/9781444325324

Cliteur, P. 2015. Is Humanism too Optimistic? An Analysis of Religion as Religion. In Copson, A. \& A.C. Grayling (eds.) The Wiley Blackwell Handbook of Humanism. West Sussex: John Wiley and Sons Ltd. https://doi.org/10.1002/9781118793305.ch19

Cooper, B. 1995. The Two-Faced Ogun: Postcolonial Intellectuals and the Positioning of Wole Soyinka. English in Africa 22, 2, October: 44 - 69. https://doi.org/10.1002/9781118793305

Copson, A. \& A.C. Grayling (eds.) 2015. The Wiley Blackwell Handbook of Humanism. West Sussex: John Wiley and Sons Ltd.

Copson, A. 2015 Introduction. In Copson, A. \& A.C. Grayling (eds.) The Wiley Blackwell Handbook of Humanism. West Sussex: John Wiley and Sons Ltd.

https://doi.org/10.1002/9781118793305.ch1

De Gruchy, J.W. 2017. The Humanist Imperative in South Africa. South African Journal of Science 107,(7-8): 11 - 13.

https://doi.org/10.4102/sajs.v107i7/8.804

Derkx, P. 2015. The Future of Humanism. In Copson, A. \& A.C. Grayling (eds.): The Wiley Handbook of Humanism. West Sussex: John Wiley and Sons Ltd.

https://doi.org/10.1002/9781118793305.ch21

Eleojo, E.F. 2014 Africans and African Humanism: What Prospects? American International Journal of Contemporary Research 4,1: 297 - 308.

Ghana Business News. 2015. Access Bank Hosts Professor Wole Soyinka in 
Ghana. Available at:

https://www.ghanabusinessnews.com/2015/07/03/access-bank-hostsprofessor-wole-soyinka-in-ghana/.

(Accessed on 12 November 2019.)

Gibbs. J. 1993. Soyinka's Writing for the Press. In Gibbs, J. \& B. Lindfors (eds.): Research on Wole Soyinka. Trenton,NJ.: Africa World Press.

Gibbs, J. 1986. Macmillan Modern Dramatists: Wole Soyinka. London: Macmillan Publishers. https://doi.org/10.1007/978-1-349-18209-1

Grayling, A.C. 1985. The Refutation of Skepticism. LaSalle, Illinois: Open Court Publishing Company.

Grayling, A.C. 2007. Against All Gods: Six Polemics on Religion and an Essay on Kkindness. London: Oberon Books.

Grayling, A.C. 2008. Scepticism and the Possibility of Knowledge. London: Continuum.

Grayling, A.C. 2015. The Good and Worthwhile Life. In Copson, A. \& A.C.

Grayling (eds.) The Wiley Handbook of Humanism. West Sussex: John

Wiley and Sons Ltd. https://doi.org/10.1002/9781118793305.ch5

Haus Der Kulturen Der Welt. 2016. Dictionary of Now \#3 | Wole Soyinka \&

Manthia Diawara - TRUTH. Available at:

https://www.youtube.com/watch?v=GQxFBe_JgrA.

(Accessed on 15 November 2019.)

Haworth, A. 2015. Humanism and the Political Order. In Copson, A. \& A.C.

Grayling (eds.) The Wiley Handbook of Humanism. West Sussex: John

Wiley and Sons Ltd. https://doi.org/10.1002/9781118793305.ch14

Humanist International 2014. Wole Soyinka's International Humanist Award Acceptance Speech. Dated 12th August 2014. Available at:

https://humanists.international/2014/08/wole-soyinkas-international-

humanist-award-acceptance-speech-full-text/

(Accessed on 12 November 2019.)

Humanist UK 2009. Anthony Grayling: Darwin, Humanism and Science,

Conway Hall. Dated 6 June 2009. Available at:

https://www.youtube.com/watch?v=HbeY9 NErCs

(Accessed on 5 November 2019.)

Humanist UK 2014. World Humanist Congress: Plenary One - A.C. Grayling on Freedom of Speech and Freedom as Such. Available at:

https://www.youtube.com/watch?v=16aWcPm4w 4 (Accessed on 6 November 2019.) 
Jeyifo, B. 2004. Wole Soyinka: Politics, Poetics and Postcolonialism. New York: Cambridge University Press.

https://doi.org/10.1017/CBO9780511486593

Joseph, C.L. 2015. The Arrogance of Faith and Religious Imperialism: Soyinka's Radical Theistic Humanism and Generous Tolerance. Journal of Pan African Studies 8,5: 19 - 63.

Labinjoh, J. 1982. Fela Anikulapo-Kuti: Protest Music and Social Processes in Nigeria. Journal of Black Studies 13, 1: 119 - 134.

https://doi.org/10.1177/002193478201300109

Law, S. 2011. Humanism: A Very Short Introduction. New York: Oxford University Press.

https://doi.org/10.1093/actrade/9780199553648.001.0001

Lee, L. 2012. Research Note: Talking about a Revolution: Terminology for the

New Field of Non-religion Studies. Journal of Contemporary Religion 27,

1: 129 - 139.

https://doi.org/10.1080/13537903.2012.642742

Lee, L. 2015. Recognizing the Non-religious: Reimagining the Secular.

Oxford: Oxford University Press.

https://doi.org/10.1093/acprof:oso/9780198736844.001.0001

McHugh, F. 2015. A.C. Grayling on How Religion Imprisons Societies and

Why he Can't get a China Visa. Post Magazine. Available at:

https://www.scmp.com/magazines/post-magazine/article/1883168/ac-

grayling-how-religion-imprisons-societies-and-why-he-cant

(Accessed on 20 September 2019.)

Melton, G.J. 2011. Unbelief: Religious Skepticism, Atheism, Humanism,

Naturalism, Secularism, Rationalism, Irreligion, Agnosticism, and

Related Perspectives. San Diego: San Diego University. Available at:

https://religion.sdsu.edu/reason/docs/reason bibliography rev7 12.pdf

(Accessed on 23 November 2019.)

Metz, T. 2011. Ubuntu as a Moral Theory and Human Rights in South Africa.

African Human Rights Law Journal 11,2: 532 - 559.

https://doi.org/10.1093/acprof:oso/9780199599318.001.0001

Metz, T. 2013. Meaning in Life. Oxford: Oxford University Press.

Mireku-Gyimah, P.B. 2013. Soyinka as Satirist: A Study of the Trials of Brother Jero. International Journal of English and Literature 4,6: 269 282.

Moyo, M. 2014. The Autobiographical Nature of the Allegory in Wole 
Soyinka's Death and the King's Horseman. European Scientific Journal 10,32. Available at:

https://s3.amazonaws.com/academia.edu.documents/37842337/The Nat ure_of_the_Allegory_in_Soyinkas_Death_and_the_Kings_Horseman.pd f?response-contentdisposition=inline $\% 3 \mathrm{~B} \%$ 20filename\%3DTHE_AUTOBIOGRAPHICA L_NATURE_OF_THE_ALLEG.pdf\&X-Amz-Algorithm=AWS4HMAC-SHA256\&X-Amz-

Credential=AKIAIWOWYYGZ2Y53UL3A\%2F20191222\%2Fus-east$1 \% 2 F s 3 \% 2 F a w s 4$ request $\& X-A m z-D a t e=20191222 T 115519 Z \& X-$

Amz-Expires $=3600 \& X$-Amz-SignedHeaders=host $\& X-A m z-$

$\underline{\text { Signature }=696 \mathrm{bd} 4602 \mathrm{f1e} 8863134 \mathrm{f} 3493807 \mathrm{ae} 8 \mathrm{a} 3 \mathrm{~b} 20 \mathrm{e} 7771 \mathrm{aa} 3 \mathrm{da} 89 \mathrm{~d} 9 \mathrm{e} 0}$ 83e6655ab929d. (Accessed on 14 November 2019.)

Obee, R. 1994. A Dialogue of Two Selves: Themes of Alienation and African Humanism in the Works of Es' kia Mphahlele. Masters of Arts Thesis. Pretoria: UNISA.

Oraegbunam, K.E.I. 2012. Humanism and the Law towards African Rennaissance. Ogirisi: A New Journal of African Studies 9: 245 - 246. https://doi.org/10.4314/og.v9i1.13

Pinn, A.P. (ed.). 2014. Theism and Public Policy: Humanist Perspectives and Responses. New York: Palgrave MacMillan.

https://doi.org/10.1057/9781137465306

Rafapa, L.J. 2005. The Representation of African Humanism in the Narrative Writings of Es' kia Mphahlele. Doctoral dissertation. University of Stellenbosch.

Soyinka, W. 1988. Art, Dialogue \& Outrage: Essays on Literature and Culture Volume 1. Oxford: New Horn Press.

Soyinka, W. 2004. Climate of Fear - Reith Lecture, 3: Rhetoric that Binds and Blind. Available at:

http://downloads.bbc.co.uk/rmhttp/radio4/transcripts/20040421 reith.pdf (Accessed on 10 July 2019.)

Soyinka, W. 2014. WGBHForum. Black Writers: Wole Soyinka. Available at: https://www.youtube.com/watch?v=QfnOJpE8G4E\&t=30s (Accessed on 15th September 2019.)

Stanford University. Presidential Lectures in the Humanities and Arts: Wole Soyinka. Available at:

https://prelectur.stanford.edu/lecturers/soyinka/ 
(Accessed on 15 September 2019.)

Strhan, A. \& R. Shillitoe. 2019.) The Stickiness of Non-Religion? Intergenerational Transmission and the Formation of Non-Religious Identities in Childhood. Sociology 53,6: 1094 - 1110.

https://doi.org/10.1177/0038038519855307

Taiwo. O. 2010. How Colonialism Pre-empted Modernity in Africa. Bloomington, IN.: Indiana University Press.

Taylor, C. 2007. The Secular Age. Cambridge, MA.: The Belknap Press of Harvard University Press.

Times Higher Education 2016. THE BRICS \& Emerging Economies Universities Summit to take place in Johannesburg. Dated 7 October 2016. Available at: https://www.timeshighereducation.com/worlduniversity-rankings/brics-emerging-economies-universities-summittake-place-johannesburg. (Accessed on 3 November 2019.)

Times Higher Education 2016. Wole Soyinka: 'Anti-humanism' Infecting Universities. Dated 1 December 2016. Available at: https://www.timeshighereducation.com/news/wole-soyinka-antihumanism-infecting-

universities\#: :targetText=That $\% 20$ is $\% 20$ the $\% 20$ powerful $\% 20$ message, young $\% 20$ mind $\% 20$ away\%E2\%80\%9D\%20from\%20dogma. (Accessed on 12 November 2016.)

Todorov, T. 2002. Imperfect Garden: The Legacy of Humanism. Princeton: Princeton University Press.

Todorov, T. 2010. The Fear of Barbarians: Beyond the Clash of Civilisations. Chicago: University of Chicago Press.

https://doi.org/10.7208/chicago/9780226805788.001.0001

Ugwuanyi, L.O. 2011. I am Therefore You Are: An Existentialist Perspective on Wole Soyinka's Writings. Unizik Journal of Arts and Humanities 12,2. Available at:

https://www.ajol.info/index.php/ujah/article/viewFile/72629/61547.

(Accessed on $15^{\text {th }}$ November 2019.)

https://doi.org/10.4314/ujah.v12i2.3

University of California Television. 2002. Conversations with History: Wole Soyinka. Available at:

https://www.youtube.com/watch?v=wosbdri9dRc\&t=372s (Accessed on 7 October 2019.)

University of Johannesburg 2016. BRICS16 Day 1: Wole Soyinka Keynote 
Address. Available at:

https://www.youtube.com/watch?v=r5j3-5c82ME\&t=115s

(Accessed on 5 December 2019.)

White, J. 2015. Humanism in Education. In Copson, A. \& A.C. Grayling (eds.):

The Wiley Handbook of Humanism. West Sussex: John Wiley and Sons

Ltd. https://doi.org/10.1002/9781118793305.ch13

Wintle, A. 2013. A.C. Grayling on Growing Up, Discovering Philosophy and the Meaning of Life. The Telegraph. Available at:

https://www.telegraph.co.uk/culture/culturenews/9933425/A-C-

Grayling-on-growing-up-discovering-philosophy-and-the-meaning-of-

life.html (Accessed on 20 September 2019.)

Zimmerman, J. 2017. Re-Envisioning Christian Humanism: Education and the Restoration of Humanity. Oxford: Oxford University Press. https://doi.org/10.1093/acprof:oso/9780198778783.001.0001

Zuckerman, P. 2014. Faith No More: Why people Reject Religion. New York: Oxford University Press.

Zuckerman, P., L.W. Galen \& F. Pasquale (eds.). 2016. The Nonreligious: Understanding Secular People and Societies. New York: Oxford University Press.

https://doi.org/10.1093/acprof:oso/9780199924950.001.0001

Patrick B.S. Pillay

Post-Doctoral Research Fellow Desmond Tutu Centre for Religion and Social Justice

University of the Western Cape

South Africa

Patrick@referencepoint.co.za 